\title{
Persuasion and the hygiene of communication
}

\author{
Ştefan Vlăduţescu \\ University of Craiova, 13 A. I. Cuza Street, 200585, Craiova, Romania \\ E-mail address: stefan.vladutescu1@gmail.com
}

\section{ABSTRACT}

The study starts from the observation that in everyday life persuasion premise is investigating the negative effects of persuasion through seducti diseases induced by persuasion would be needed a medicine of com nic persuasion should be accepted: people have to get used to live with rersuasion. taken into account if not eradicate, at least mitigate the negative ito of persuas for such an approach would be "hygiene of communication" in elements of communication.

Keywords: persuasion; persuasive communication; communication

\section{INTRODUCTION}

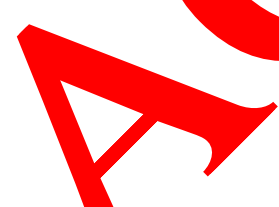

edicine of communication; hygiene of

Persuasion exercises a $\mathrm{d}$ ble $\mathrm{p}$ essure or the opinion: of arousing the excess and the supply of reasons for chare. the grounds for subjecting to pressure are persuasive and specific ools are d: seduction, lie and myth. Persuasion releases the natural opinion and $\mathrm{c}$ lictorily $\mathrm{p}_{\mathrm{s}}$ it to public expression. It provides protection to this expression, cro ting logical and social-psychic conditions of implantation by influencing a se caried collec opinion: an attractive and confident one (Boengiu, 2002; Borowski, 20 3). Th persuasiy approach is assumed in different ways. Persuasion wins and agglutinates ip alvidua by myth, by the call to the powers of the unconsciousness, through terror an hreat. ersuasion changes the social structure with the purpose to remove the gostac which $\mathrm{s}$ its expansion and vitiates its effect. It is also acted through rational ey atio s and exposure of deeds, without coming out of the myth and lie, meaning of the fiction may said that fiction operates in all forms of persuasion, alone or supported, aided, p ed by seduction. Fiction, myth, lie are impregnated by seduction, the yield of negative jo rnalism would be just as higher. The extraordinary possibilities of persuasion make a terrible threat float over the world. Persuasion is the most feared informational aggression. In this way, true psychological epidemics can knowingly be caused (Vlăduţescu, 2004; Borowski, 2014; Powell, 2014). Through engineering of subjects, negative journalism produces individuals with automatically controlled opinions, attitudes and behaviours.

Psychology, sociology and communicology add a mass communication strategy to the seductions and lies, fictions and myths, rhetoric subtleties and demagogic artifices through negative journalism. Persuasion represents an extension of the operations of irrationalaffective communication on an invisible dimension of masses. Not being done specifically 
for persuasive effects on the masses, persuasion is however done for the masses. It is specifically and increasingly more consolidated in order to attract and reach the masses. Persuasion articulates an equally important process on this process of persuasive flattery: of contempt and defiance of the masses. Flattering the masses (just like adulation) derives from seduction. The process of disregarding the masses occurs in two undertakings: ignoring the masses as assembly of beings and minimising the spontaneity of their participation as people.

Ignored, the public is used as entertainment being. Flatter and contempt are behind the rhetoric of persuasion. With their help, negative journalism distorts or triggers social forces. The persuasive ideas transferred through influence, intoxication, propaganda, manimutotion, disinformation and rumour, as well as through other forms of persuasion becom rorces, $\mathrm{d}$ by means of masses - social forces.

\section{GENUINE COMMUNICATION AND PERSUASIVE COMY NICA TON}

As it is known, the topic dealt with in an editorial proy des the s. tha ght to the mass on the same day. The persuader possesses the thoug a mass. I negatively modulates this thought, persuasive communication shall th $\mathrm{k}$ at mass level. In order to become negative, journalism does not require effort is great ef are to be positive. Everything else is considered to be negative (Shop vski, 2012; De la Rosa \& Shopovski, 2013). It can be negative due to any failure of t positive, die to any error. From this perspective, negative journalism appears as "unavo ble". Hoy ever, if a persuasion is also implanted voluntarily as main exhibit ip negativity negative journalism becomes fundamentally negative. To be in one way o war at the level of the huge power which it has available anyway, journalism has all ne ess y and all possibilities open. It has technical means and a wide audienae of the indeciced, hesitant and disoriented. For this audience, negative journalism b ings scuing formation in the most innocent and delicate way of the disaster. A perver lvat on is per uasively provided to that who is lost in their own uncertainties. The eff of atru mualism is guaranteed. It results from here that persuasive communicat is the sh path to the effect. Instead, the short part of rational communication is $\mathrm{dif}^{f} \mathrm{cu}$ forces in a huge effort of permeability, it is the royal path.

In reality, ra a con unication has its title of royal path exactly due to the very existence of ne gative journalis In the absence of negative journalism, positive journalism would be at he rea of the undifferentiated. Both types of communication are moving towards a po al of e panding influence. The masses have an increasingly broader intelle perin $\sigma^{f}$ absorption towards influence. Communication responds to the ava abilit of influc which the audience shows. It seems it responds particularly through pers ior moning negatively, and not through conviction, meaning positively. The journa ic influence is not communicational, the influence is directly and shockingly real. Commun on has a power that cannot be neutralised or anesthetised. If communication would also oe immune to the persuasion it fights, then it could be the first power.

Because it is normal, communication misses the chance to be the supreme arbiter. The favourable circumstance is incomplete and because persuasion itself has a negative side. This side, which is impossible to eradicate because it is part of the impelling mechanism, should be managed scrupulously. Its well awareness belongs to this management project (Arsith, 2014).

Persuasive communication presents a scenario dedicated to the frame of prefabricated intellects. Once it is born, the child opens itself a new rainbow to the unconscious, if the child 
is conditioned by diffusers reaching its unconscious, if afterwards a path is delimited for the child within its family, at school and in the society, a path where for an infallible direction they shall be channelled on the line of a programmed destiny: this is a prefabricated intellect. Used to the spices of seduction, lie and myth, in its innocent predestination, journalism does not hesitate to disguise into the opposite, meaning perfidy, flattery and despise. From the ideal of correct information, persuasion chooses flattery and aversion. Once accustomed to flattery, adulation, despise and aversion, communication is utterly and completely persuasive. The consciousness of perversion is covered with the idea of self-defence, of provoked response, of induced obligation. Nobody provokes, defies, forces the communicator to be persuasive if the latter's responsible consciousness does not allow them to be such. consumer of journalism must protect itself against persuasion. Therefore consun would be interested to force the journalism to be positive and rational. $Q$ ne is vever $n$ fully decided in this respect: one's decision is even the product of negati e journalis

There is a solution for the fictive-fabling component of the rechar $m$ gen ating persuasion in all its forms. There is the Domenach solution agai lou atism of fabling orientation: "Against the invasion of the lie and myth, w need to and strengthen the power to refuse, which there is not morality or intellige a ithout" (b nenach J. M., 2004, p. 148). Fabling must be suspended, otherwise the enera mechanism seizes up. The consumer must fortify in order to withstand the drasuting call the myth invoked by negative journalism. In order to save themselves, th consumer is for ed to begin an unjust crusade against the myth that is provided to them a educing ref 'ge, as accessible grandeur, as an available comfort.

Persuasion can be counteracted. Dissuading may apitalising the central right in freedom: the right to refuse. There is gen munication only where the audience is correctly informed, where it is invited, call a know and participate. Authentic communication pretends a wide diffusion knowedge; it is not a matter just about instructions of intellectual traing, basica $v$ of knowing the issues (Neaca \& Neaca, 2011).

In reality, communio rs the real issues, considering that the terms according to $y$ ich the is must be raised and solved are the same. It is an error which it interestedly rop tes: the to ns according to which the problems are raised do not coincide with the rins acco to which they are solved.

We are d aling with a ma irony: persuasive communication leads to perfection the art of preventip veopl stick heir noses into affairs which do not concern them. By the persuasive too as as to to bring the audience into the situation of being disinterested of its re oblen and of getting socially involved into the issues created within com nunic ion. It 1 secret which mass communication enterprises hide under the setting age $T$ mass-media produces the agenda. The massmedia Tity tenus to be a prefabricated one, and in the case of negative journalism, it fully succeeds Only if hardly does the communication opens a debate on this topic from time to time, bu however never definitively and resolutely a substantial debate. Strange this type which is not willing to explain the credits in seduction and fabulation!

Its hygiene of communication pretends that all is well (Kot \& Ślusarczyk, 2013; Kot \& Ślusarczyk, 2014). Only thus can the power flaunt. Persuasion can only be combated by a journalism that is well consolidated in democracy, one which could also afford among other things: public documentation offices, official press releases to update the public opinion on economic, social, demographic issues, development of the anti-negativism legislation, 
extension of the right to respond so that the lie issued to block with sets of replies those pages which caused it, etc.

Audience's salvation lies in participation. Correctitude and honesty can exercise their legitimacy only as such. The non-genuine needs lie beyond the legitimate participation, needs which negative journalism engage in intoxication, disinformation, influence, rumour, propaganda, diversion or manipulation, by fabling and seducing.

The legitimate participation generates dialogues, and the persuasivity is suffocated in dialogue. The communicational consciousness may thusly be balanced. The legitimate participation in dialogues shall have a sacred aspect by instauration. People shall movoinside it, remaining at the fingertips of a shared piety. A certain respect shall be install $a$, a fer $r$ which shall be given by recognising the legitimacy of the other's opinion. Th not a my such as those which proved their harmfulness by inducing the fanaticism It in a my brought to delirium, it is not a myth of persuasive fabling shaping. It $j$ a state or ings to attenuate the power of negative journalism. This profane man must e cy so thing cred: the legitimacy of participation. This joy is amplified and also vitia d b ative $j$ rnalism. By capitalising the social inertia of phenomena, persuasio develop if it were a specifically cultivated plant, and not an obstruction plap Newsom d B. Carrell conclude that people in the society nowadays "support mos of the decisions and behaviour on emotions, not on logic" (Newsom D., Carrell B., 2 Tu, p. 60). purchasing a certain car or of supporting a certain political candida,e, it seems that most people take decisions based on impressions rather an on intell gence (Deaver F., 2004, p. 149). There is evidence likely to make us believe th mpressior s are created and influenced by means of the mass-media messages, th source o. them being the publicity or public relations. Persuasion is the short way minimum effort, the emotional way.

A critical sense (a common sense) rem ins nostalgia of evidence, a sense that may censor the opinion. This critical sense is atenuated by the morals of respecting others' opinions. Instead, it represents a gu ntee o validity, based on the idea that it raises a sovereign contempt against f cisn on the ath of contempt, the critical sense is shaped as obstacle in the way of at critical sense is an obstacle, but not a limit (Vlăduţescu, 2008; Zam \& Vlădù, u, 2003).

Another suppe on rsuasive ommunication is also another positive element: that who is truly convi cal of so thing shall seek to make others also believe in that something. Trusting somet' 1 ng is a solid. ament to consider that another should also believe in that something. truly lieving an something leads to not promoting that something. The two pillars of nega journa $m$ ensure it permanently and it shows that unless we have the necess aith w apable of leading to the propagation of value. The human dedicated to $y$ idea elieves th a faith which life does not continue without! "To be true, said A. Can on the notinue". Those who do not believe in their ideas, in their vocation, they do no Teve in their own future. We conclude that persuasion is a natural manifestation of the socie, $t /$ is a major wrong what persuasive communication does, but it is a developing wrong, a nccessary wrong (Seceleanu, 2008). We can combat this wrong, but we should not make it our impossible ideal to eradicate it.

The wrong that is produced cannot be denied (Efrim, 2011; Vărzaru \& Jolivet, 2011). But us, who blast persuasion, can we imagine it is sufficient in our world that truth would just appear and shall immediately be recognised?

The truth is difficult to recognise. If it is difficult to recognise, then it shall be firstly recognised by some. We know it is not enough for the truth to survive if it remains in the heart of a few initiates. When those few initiates would perish, the truth would disappear. In 
order to survive, truth must be propagated. Persuasion does not have a separate truth. It propagates a truth of appearance. The death of persuasion would configure the method according to which the truth would die by non-propagation (Roşca, 2012). Persuasion must therefore be controlled, but not dissolved. In order to control it, it is necessary we thoroughly study it. It is useless to consider we could secure the propagation of values through purism now when the issue is in terms of mass. It would be just as useless to say that we could extirpate persuasion by a concerted mysticism of overall public honesty.

\section{CONCLUSION}

Rational communication and persuasive communication are mixed Who ve valu appear in various forms, them purify equals to unbalancing the mechan om of man $n g$, $\mathrm{d}$ propagating the values. It is known that although it is not exactly d red so the tru may also be promoted through lie, the good is also spread through the ron istice a bexudes from injustice. It can be said that, without this being the ide and pr ence a rational communication is achieved through persuasive communicatic 1. better to etitively note this before not observing the difference anymore. ACKNOWLEDG ENT
This work was partially supported by the grant number $33 \mathrm{C} / 2$
the University of Craiova.

\section{References}

[1] G. E. De La Rosa, J. Sho ki, E siing Lay Review 4(04) (2013) 174.

[2] Andrzej Borowski, Iy ermation Tetters of Social and Humanistic Sciences 14 (2014) 7-17.

[3] Jason L. Power, aterno al Letters of Social and Humanistic Sciences 16(2) (2014) 177-183.

[4] Sebasti ot, Jallosz Grabara, Michal Kolcun, International Letters of Social and Humanistro ences (2014) 1-6.

[5] Bu nociologia opiniei publice. Bucureşti : Editura Didactică şi

[6] Jo Shopovski (2012). Legal framework concerning gender equality in Republic of Mace Ya. In Book of Proceedings, (p. 324.

[7] A. Seceleanu (2008). Comunicarea politică în spaţiul mediatic. Editura Fundaţia Andrei Şaguna.

[8] Ştefan Vlăduţescu (2008). Mesaje şi texte gânditoare. Craiova: Editura Sitech.

[9] Silviu Neacşu (2005). Sistemul informaţional statistic în învăţământul românesc după 1990. Ed. Fundaţiei Univ. pentru Toţi.

[10] Carmen Banţa, The Staircase in a Block of Flats-a Vertical Rural Alley. Past vs. 
Present. (A Case Study: the Craiovița Nouă District, Craiova). Analele Universităţii din Craiova, 28.

[11] Ștefan Vlăduțescu, International Letters of Social and Humanistic Sciences 20 (2014) $37-45$.

[12] Andrzej Borowski, International Letters of Social and Humanistic Sciences 14 (2014) $33-41$.

[13] M. Colhon (2013). Automatic Lexical Alignment between Syntactically Weak Related Languages. Application for English and Romanian. In Computational Collec Intelligence. Technologies and Applications (pp. 266-275). Springer Berlip Aeidelbo

[14] Mădălina Cerban, Nicolae Panea (2011). The Act of Performance as Hosp Pasado, presente y futuro de la cultura popular: espacios y context s. Actas VV Congreso de la SELICUP (p. 26). Universitat de les Illes Balears

[15] Max G. Craig, Journal of Studies in Social Sciences 8(1) (20)

[16] A. Traistaru, M. Avram, International Letters of Social oumanist nes 13 (2014) 79-88.

[17] Andrzej Borowski, International Letters of Socia Mana Yumanis Mences 4 (2013) 70-74.

[18] D. A. Efrim (2011). Rolul Autorităților Admin rative Locale În Înfăptuirea Funcției Educative a Statului (The Role of Local Adminu vive Av horities in the Accomplishment of the Educative Fun of the Stunc. Coord. Dan Claudiu Dănișor, George Gîrleșteanu-Democrația partici Ativy
Universi informarea cetățenilor,

[19] I. C. Dima, Ş. Vlăduţescu, uro, in Jour, vof Business and Social Sciences 6(1) (2012) 27-33.

[20] A. Borowski, Intery anonal L rs of Social and Humanistic Sciences 11 (2014) 1-168.

[21] Mihai Vărzaru, no ntoaneta arzaru, Annales Universitatis Apulensis-Series Oeconomicg 15,2$)(20$

[22] Mihai V̌̆zaru, Eric Jolive, The Amfiteatru Economic journal 13(30) (2011) 620-631.

[23] Mitica h i neas Andreea Maria Neaca, Journal of Materials Science and En-ineerin 1(2) 2011) 170-177.

[24 Sand Boengiu Revista de Geomorfologie, 4, 2002.

[25] . IIturu Ştefan Vlăduţescu (2003). Percepţia şi audiopercepţia, o abordare $c_{0}$ viv-constructiv-operaţioanală. Bucureşti: Editura Didactică şi Pedagogică.

[26] Andrzej Borowski, International Letters of Social and Humanistic Sciences 2 (2014) 110-121.

[27] Națalita Maria Sperdea, Maria Enescu, Marian Enescu, Economics, Management, and Financial Markets 2 (2011) 200-205.

[28] I. C. Dima, Ş. Vlăduţescu, International Journal of Management Sciences and Business Research 1(9) (2012) 1-11.

[29] M. Nowicka-Scowron, I. C. Dima, Ş. Vlăduţescu, International Journal of 
Management Sciences and Business Research 1(8) (2012) 27-35.

[30] Calbureanu M., Albotă E., Malciu R., Lungu R., Calbureanu D., “Advanced computational concepts about projecting a multiple designs of self-supporting metallic structure using Finite Element Method in determination the buckling factor and running the stress analysis", WSEAS TRANSACTIONS on APPLIED and THEORETICAL MECHANICS, WSEAS Press, 5(3) (2008) 186-195.

[31] Mirela Arsith (2014). Managerial Communication in the Context of Organizational Change. EIRP Proceedings, 9.

[32] Daniela Dincă, Analele Universităţii din Craiova. Seria Ştiinţe Filologidon ngvistică, 1 (2009) 79-90.

[33] Ştefan Vlăduţescu, American International Journal of Contempo ary Re arch (2013).

[34] C. Teisanu, S. Gheorghe (2011). Development of New PM ron-Basec vtey als for Self-Lubricating Bearings. Advances in Tribology.

[35] Vlad Roşca (2012). The Political Economy of Worl Lavywe Boxing during the Great Depression. Theoretical and Applied Eco omics, 1(1), 127.

[36] S. Degeratu, P. Rotaru, G. Manolea, H. O. Ma lea, A. Rota u, Journal of thermal analysis and calorimetry 97(2) (2009) 695-700

[37] Ștefan Vlăduțescu (2004). Studii de P logie genorad şi Psihologie socială. Craiova: Editura Sitech.

[38] Cristina Coman (2001). Relatiile publice. rincipht şi strategii. Iaşi: Polirom.

[39] Mădălina Cerban (2010). vntac relatio, versus semantic roles within relational framework. Analele Unর tăț

[40] Janusz Grabara, M hal Kolcu. Sebastian Kot, International Journal of Education and Research 2(2)

[41] Andrezj Bo ysi, Inte, ronal Letters of Social and Humanistic Sciences 3 (2013) 69-74.

[42] Janusz a, Stef Novak, Agnieszka Ulfik. Selected aspects of sustainable tourism devalopme, the 1 cal government.

[43 Aure A Traista (2013). Consolidation of the green marketing profile in current d. Jokull.

[44] Șt $V$ Văduțescu, International Letters of Social and Humanistic Sciences 15 (2014) 164- 0 .

[45] J. H. Gasderell, International Letters of Social and Humanistic Science 22 (2014) 85-91.

[46] Janusz Grabara, Vladimir Modrak, Ioan Constantin Dima, International Letters of Social and Humanistic Sciences 15 (2014) 148-156.

[47] Ştefan Vlăduţescu, International Journal of Education and Research 1(12) (2013).

[48] P. Bajdor, I. Grabara, Journal of Studies in Social Sciences 7(2) (2014). 
[49] Tomáš Hes, Anna Poledňáková, International Letters of Social and Humanistic Sciences 2 (2013) 18-31.

[50] Mohsen Mehrara, Masoumeh zirak, International Letters of Social and Humanistic Sciences 2 (2013) 32-38.

[51] Andrzej Borowski, International Letters of Social and Humanistic Sciences 3 (2013) 46-53.

[52] Donovan A. McFarlane, International Letters of Social and Humanistic Sciences 4 (2013) 35-44.

[53] Kinga Dziwańska, International Letters of Social and Humanistic Science 7 (2013) 96-112.

[54] Mohsen Mehrara, Maysam Musai, International Letters of Social Sciences 8 (2013) 1-7.

[55] M. Brie, I. Horga, Studia Universitatis Babes-Bolyai-Studio cumopa 1 (201, 63-86.

[56] Mădălina Cerban (2013). Rehabilitation of the Mother Adult Learners. Procedia-Social and Behavioral Scin as. [57] Florica Iuhaş (2013). Religious conflicts in toda s mass media. K Ista de Stiinte
Politice.

[58] Ştefan Vlăduţescu, European Scientific Journa 32) (2013).

[59] Anca Parmena Olimid (2014). Recent Mances in an Research and Management. Analytical Concepts Determining Para $7 \mathrm{gm}$. $\mathrm{ft}_{\mathrm{H}}$ in Security Policy Agenda in the 2000 's. Revista de Ştiinţe Politice.

[60] D. A. Efrim, G. Zanfir, M. MOn (2013) The Hesitating Steps of the Romanian Courts Towards Judicial Glogy on EU I aw Matters. Available at SSRN 2261915.

[61] A. Ulfik, S. Nowak, om hal of Lnvironmental Studies 23(3) (2014).

[62] Sebastian Kot, B cau lusarczyk Outsourcing Reasons and results - Survey Outcomes Disa ssion, Journal of American Business Review.

[63] Cătălina Maria Georgescu. 14). Interpreting Continuity and Change in PostComm $\mathrm{Po}$ Making: Applying the New Historical Institutionalist Approach to the Study ublic $O$ ganizations. Revista de Ştiinţe Politice.

[64] oev an Ko, a Ślusarczyk (2013). Aspects of Logistics in Biomass Supply for Ener v Produc Ion. Applied Mechanics and Materials.

[65] D. Tlaauțescu, International Letters of Social and Humanistic Sciences 10 (2014) 100

[66] Jason L. Powell, International Letters of Social and Humanistic Sciences 7 (2014) 22-30.

[67] Ștefan Vlăduțescu, International Letters of Social and Humanistic Sciences 7 (2014) 8-13.

[68] Jason L. Powell, International Letters of Social and Humanistic Sciences 17(1) (2014) $1-60$.

[69] Mohsen Mehrara, Hamid Abrishami, Mostafa Boroujli, Mahan Amin, International Letters of Social and Humanistic Sciences 11 (2013) 76-83. 
[70] Bahram Meihami, Hussein Meihami, International Letters of Social and Humanistic Sciences 3 (2014) 80-91.

[71] Rajesh K. Yadav, Nishant Dabhade, International Letters of Social and Humanistic Sciences 4 (2013) 49-69.

[72] Tomáš Hes, Alena Neradová, Karel Srnec, International Letters of Social and Humanistic Sciences 7 (2013) 55-75.

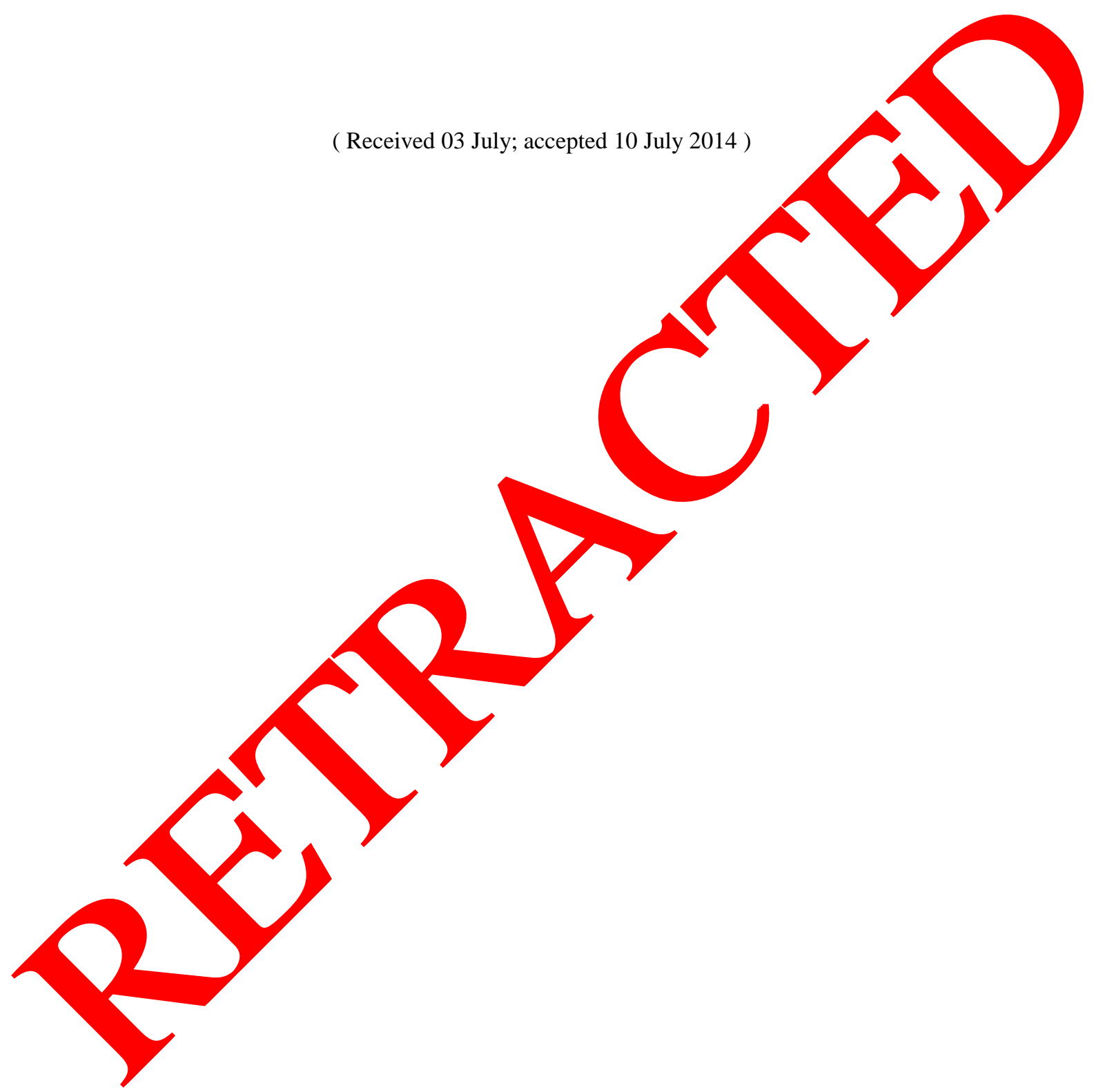

